\title{
THE LIVING DEAD: THE AFTERLIVES OF ANIMALS IN MUSEUMS
}

\section{Emma Burns}

The animals in the collections at Otago Museum have surprisingly busy lives. It is the same in many natural history collections around the world. While the original colonial collector of creatures in the past did so for pleasure, leisure, and educational display, new roles for fauna collections continue to emerge. The creatures in our care are kept with a purpose that continues to change and grow in relevance with the times. They allow new questions to be asked, in new ways and for new reasons; questions about them and of ourselves. Today these collections play a fundamental role in defining and archiving biodiversity - and becomes primary evidence of change and loss.

Museums worldwide have a bit of an identity crisis to work through. What is a modern museum? Who is it for? What does this look like in practice? Popular philosophies around creating outward-facing, inclusive, contemporary, infinitely engaging, highly entertaining, haptic, attention-grabbing, 3D sensory experiences, that will inspire and wow audiences, can create quite heady goals. For natural history museums and their collections, while some aspects of these ideas are important in fostering and reinforcing connections with the natural world, they limit the view of what the role of these collections play in society, which is arguably more than entertainment. The goal of a modern natural history museum should be to support our understanding of nature. How that works in practice should also be an evolving dialogue with our communities.

Members of the public and funders often focus their definition of a museum's purpose on public displays. It's what they are familiar with. They are often stunned that less than $1 \%$ of the Natural Sciences collections we hold at the Otago Museum are displayed. This is not unusual.' The bulk of the specimens were not preserved and collected with a display in mind. ${ }^{2}$ They are comparative collections built up over, in Otago's case, I 50 years, for educational study and research.

For practical purposes, what we select for display is skewed toward the attention-grabbing charismatic megafauna. There are not shelves upon shelves of whales, elephants, lions, albatross and monkeys in storage. What's upfront is often the only specimen we have. Logistically, it is easier to have the big items displayed rather than in storage. In the same physical space we use to house one whale, we could store tens of thousands of invertebrates. These are practical discussion points, because for those working with natural history collections - curators, collection managers, and conservators, we have an important but often unseen role, doing some very practical things, which is often overlooked in animal conservation circles and researcher's academic papers.

Sometimes people find what we do a little uncomfortable, and morbid, and weird. We do spend a lot of time with the evidence of death, and in thinking of extinction, loss, change, fleeting time, and our own animal origins. As a curator, I realize the privilege of it, but I'm not precious about it. Death, for everyone, is the unavoidable flipside of life. In the Otago Museum's case, the moment of death has often already happened. People bring us kererū hit by cars, possums caught in traps, penguins washed ashore dead, and invertebrates collected by entomologists over decades of work. Our collections team's job is to intercept remains of selected flora and fauna, and fossils that would otherwise decay, be discarded, eaten or eventually eroded (destroyed by nature itself). Foregoing these natural processes, we step in with unnatural ones. We preserve the remains, preparing them for their afterlives in museums as taxidermy, cleaning, pressing, pickling, and pinning. This staves off decay, 
but specimens will still age and deteriorate. Given enough time, everything does. Once preserved, they become envoys for their kin and their environment, representing a species, from a specific place and time. Their data is recorded on labels, in collection notes and computerized catalogues. To elongate the animal's afterlife as much as possible, museum's employ conservators and practices to protect specimens further. In climate-controlled, dark rooms, their individual needs are assessed and treated.

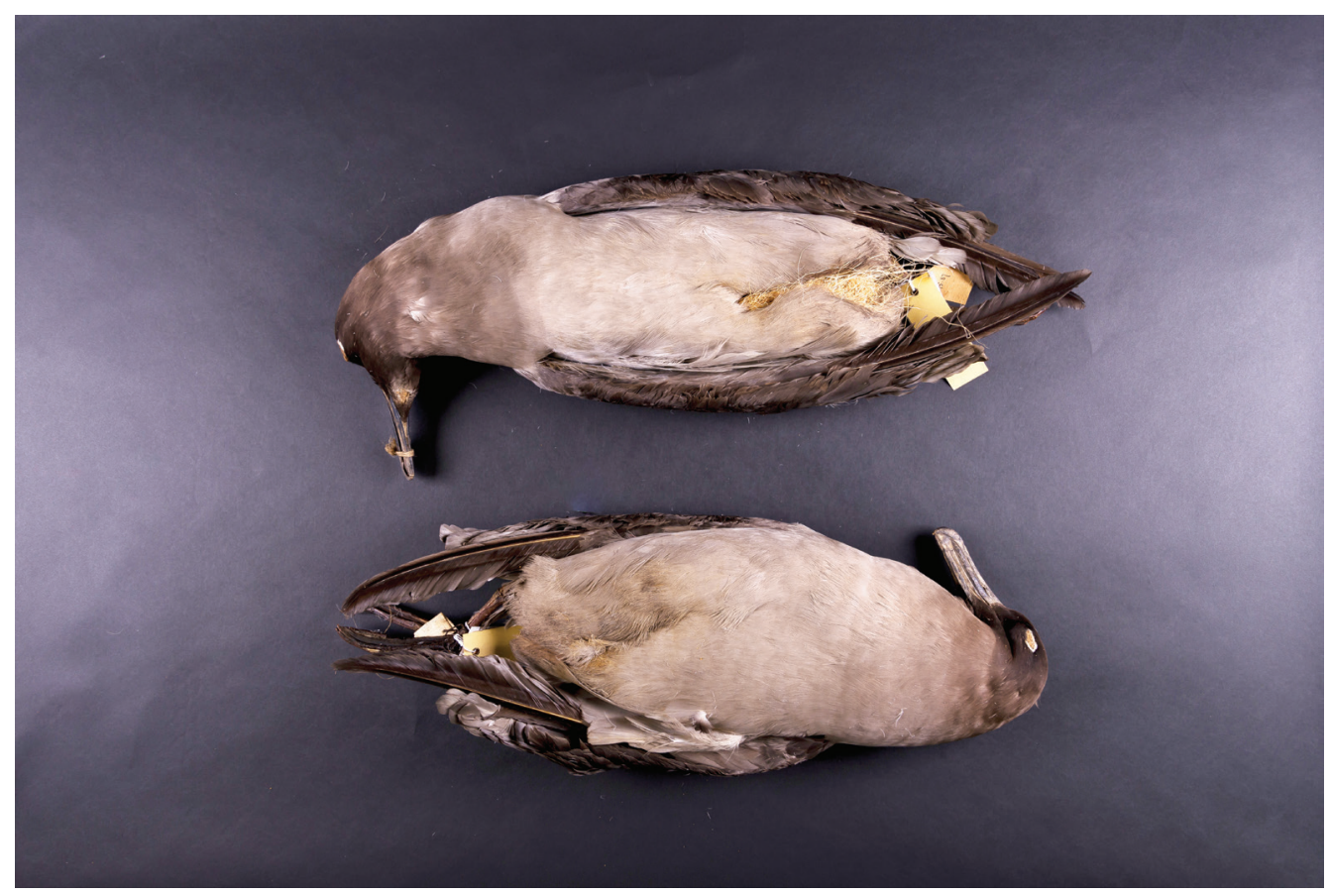

Figure I. Historic study skins, light-mantled sooty albatross (Phoebetria palpebrata), AV08I and AV082, Kane Fleury (C) Otago Museum, Dunedin.

Museum natural history collections are more akin to an archive. ${ }^{3}$ If you are pun inclined, you could call it an Ark-hive - a library of life. In the same way, you take a book off a shelf and read from its pages, people visit the collections to study the living dead, the objects, the specimens, the animal. Like document archives, the animals in natural history collections are organized using taxonomic nomenclature, a strict international classification system for assigning names to organisms, based on shared characteristics. Traditionally, taxonomy was the main purpose of natural history museums - to find, describe and house new species.

Today a steady stream of emails roll in from researchers requesting to examine the different collections. They are interested in skeletons to extract DNA from or study the physical characteristics of; in keratin from feathers, claws, and baleen to provide stable isotopes (chemical signatures used to understand diet); study skins to investigate plumage variations; and historic data points for surveys in areas where land use is quickly changing. There are many different ever-developing techniques to converse and ask questions of the dead in our care. There is no rest for the dead in a museum.

Some critics still hold the view that museums are just full of "old dead stuff", and ask if there is a place for natural history museums in modern society? In the face of climate change, massive habitat loss, and continued exploitation of the natural world, the answer is yes (now, more so than ever). On our planet, there about 2 million known 
species, and at the 2019 UN Summit in Paris, a report tabled that I million species were at risk of extinction (those species known to science). But there could be anywhere from 5 million to 100 million species on the planet. In the same way astronomers talk about the unknown universe beyond our solar system, there are still vast amounts of unknowns in the natural world, right here on Earth. ${ }^{4}$ While new species continue to be found and described all the time, it is likely that many go extinct without notice. Increasingly, new species are identified from specimens collected 50 to 100 years ago, with the use of ancient DNA analysis. Where once their identity was clumped with a close relative, we suddenly find a distinct species. In some sad cases, they no longer exist, and these new species are instantly extinct. ${ }^{5}$

We still live in a very anthropocentric society that struggles to see the benefits of protecting enough wild places for the species we share our planet with. Politically, we are left desperately short on ways of assessing and communicating the value of what we are losing. But biodiversity can be measured: the fewer species in an area, the less biodiversity there is. We rely on taxonomy to describe species as units of biodiversity. This requires revisiting historic "type specimens", the formal exemplars of a species held in museum collections, to determine if something is new or known. In New Zealand, many of our species are found nowhere else on earth. Both species of New Zealand bat are endemic, as are all four frogs, all 60 reptiles, more than $90 \%$ of insects, and a similar percentage of marine molluscs, about $80 \%$ of vascular plants and a quarter of all bird species. ${ }^{6}$ Many are poorly described, and vast numbers remain to be discovered and described taxonomically. Taxonomists themselves are threatened species in New Zealand; it is a workforce that has been in decline for many years. ${ }^{7}$

To work around skills shortages, both in the past and in the present, museums have often done exploratory and basic survey collecting of flora and fauna from specific areas. Sometimes all the samples sit unsorted, sometimes those that are easily categorized get identified. More tricky individuals might be sorted into their higher classification levels, family or genus. They are then put on a shelf, waiting for a fresh set of expert eyes, maybe the next generation of taxonomists, to visit and examine them. This is why there is an often-published trope of a new species being found "hidden/languishing/locked" in a museum's cupboards. The truth is they are not hidden at all, they are just waiting to be further studied. When people say that the museum is full of "old stuff", I tend to say good, they are doing at least half of their job. The other half is that they should also be strategically adding new specimens to the natural history collections to maintain and build the reference libraries of life. Here's why.

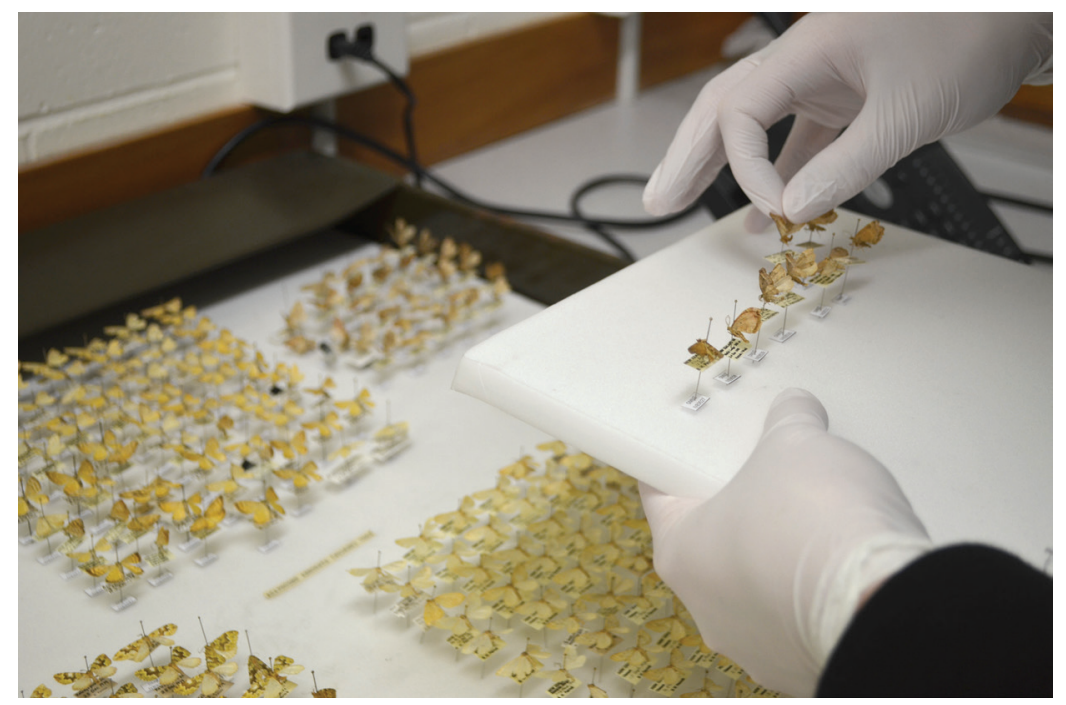

Figure 2. Trays of pinned geometrids moths, collected during surveys and opportunistic collecting, now have a growing importance in ecological research, Kane Fleury (c) Otago Museum, Dunedin. 
Each natural history specimen vouchered into a collection, with good information about where and when it was collected, becomes a priceless window into the past as a tangible object that can be revisited for different purposes. These specimens help researchers to study change: change in distributions, population genetics, environmental impacts of climate change, diet, pesticide use, and also our cultural attitudes towards different species. ${ }^{8}$ How we as humans perceive the world is subject to a type of bias called "shifting baselines". Due to our short life-spans and unreliable memories, humans have a poor conception of how much of the natural world has been degraded by our actions. With each generation, our "baseline" of normal shifts. This means that what we see as pristine nature today would be seen by our ancestors as hopelessly degraded, and what we see as degraded, our children will view as "natural". Museum collections offer testable evidence of change. But because change is constant, by not collecting, we are closing those windows into the past, and might as well turn out the lights.

Visitors to the museum stores ask questions like, do we really need I 50 specimens of flax looper moth? Yes, everyone is unique and has something to add to a data set. Across that group of 150, you are likely to have representatives of different sexes, physical variations, morphs, and genetic variations from different sites, and different times. There could also be ephemeral data to be gained from things preserved on the moths, like parasites and pollen grains.

The dead in museums can also play an important proxy role, reducing pressure on living populations. Cambridgebased Professor Gordon Hull has created a global gorilla resource, tracking down approximately 950 skins, 2500 skulls, and 1650 skeletons (that's 5100 individuals in museum collections worldwide). There are also many hundreds of histology samples (blood, urine, tissue etc) and slides maintained in many zoos. The published list, including the Otago Museum's gorillas, is an important resource, allowing researchers studying health and pathology issues of gorillas, to examine existing material to understand how to save the living of this critically endangered species. ${ }^{9}$ Our collection managers plug away in the background, cataloguing specimens from catalogue cards, swing tags, and digital records, so we can work towards liberating similar information on international aggregator websites. If researchers know where the resources are, then our biodiversity libraries (aka the natural history collections) become more useful, reducing the need to resample what might already be a dwindling population, as well as to hone techniques or add more power to data sets or model outcomes under different climate scenarios.

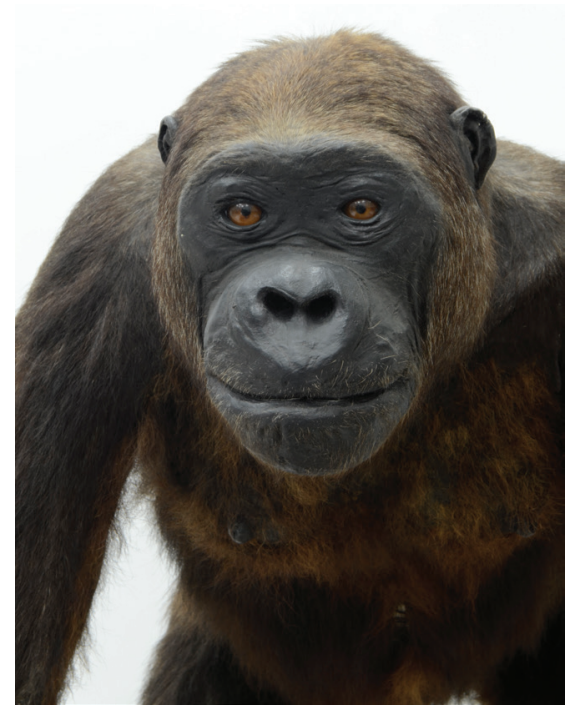

Figure 3. Female gorilla (Gorilla gorilla), purchased from Rowland Ward Studio 1930s, VT242I (C) Otago Museum, Dunedin.
In an example closer to home: tuatara were once found throughout New Zealand. There is evidence of this in museum collections of cave remains and midden material. Today, wild populations are restricted to 32 off-shore islands in the Cook Strait and northern New Zealand. ${ }^{10}$ The ultimate goal for tuatara conservation is to remove predators and re-establish thriving mainland populations. But because ambient temperature affects tuatara health, as well as determining the sex of offspring, care needs to be taken before approving translocation sites. To determine where in New Zealand tuatara could be the most successful, now and with a changing climate, $\mathrm{PhD}$ candidate Scott Jarvie from the University of Otago's Zoology Department created a scientific model. He visited us to 3D scan the Otago Museum's tuatara collection, to collect accurate proportional measurements of body length to skin surface area. This process is tricky to do on live tuatara, but an important factor in developing the modelling equations for an animal where skin surface plays a crucial role in thermoregulation. " 


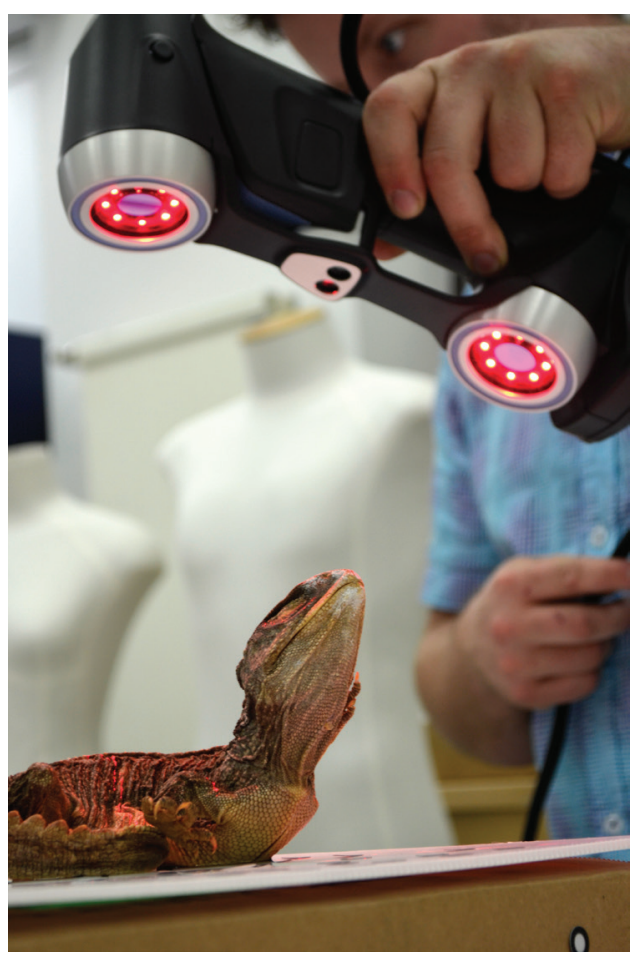

Figure 4. 3D scanning a pickled tuatara (Sphenodon punctatus) for Scott Jarvie's tuatara research, 2015,

Emma Burns (C) Otago Museum, Dunedin.
In my role as curator, we don't collect randomly, but do so in line with a collection strategy that identifies priorities for collecting, and filling in gaps in an everevolving research program that focuses on the environment, attitudes, climate change and biodiversity of the region. When I decide to add an animal to the collection, there is generally some sort of anticipated purpose, but in the same way that my predecessors would be blown away by the techniques now used to gain information from the collections, I have little idea how future technologies will be applied to these collections. ${ }^{12}$ Part of my role is spent researching and adding information to records that help contextualize collections within their individual object histories. Without these, it is easy to make assumptions that can unintentionally affect researcher's results, as well as the perspectives of the visitors to our exhibitions. These contexts can be at a practical level, like researching the history of chemical preparation methods of the pickled specimens that were popular during different periods and with different collectors. These can be factors that affect the successful future sampling of specimens for DNA and isotope data.

At a philosophical level, it is also important to question established truths about society and what we consider "common knowledge". Museum collections are artefacts that reflect the material culture in which they were collected. What is kept in collections are

loaded with inherent bias, which curators help researchers and visitors to navigate. These biases may be based on an institution's strengths (one of ours is spiders), weaknesses and priorities through time (dinosaurs are one of ours because very few have been found in New Zealand), what species are easier to preserve (not jellyfish), what is showy (stuffed birds), versus what is perceived common (New Zealand's commercial fish species), and what was important to people collecting at any particular time. Over time, society shifts, fashions fade, and power, politics, and priorities change. With the benefits of hindsight, better tools and more diverse points of view, we can more easily identify bias. Recently, research lead by Natalie Cooper looked at the bird and mammal collections of five of the biggest museums in the world and found an over-representation of males as the type specimen. ${ }^{13}$ Ecological studies have mapped museum collections and ecological survey data, and found that collecting locations often correspond with road and river networks, which means ecological distribution modelling has to factor in this skewed coverage. ${ }^{14}$

Despite millions of species on Earth, most natural history museums have a certain déjà vu to the displays. Somewhere there will be a tiger, a cast of an archaeopteryx fossil, a giant clam, and probably a kiwi. These represent a historical bias, based on colonial trade routes. Historically, opulent exhibitions were held around the empire, to entertain and boost trade. They displayed the riches of a region, showcasing natural resources. New Zealand's first World Fair, The Exhibition of New Zealand, was held in Dunedin in 1865. A collection of geology and taxidermy was displayed under the labels "Otago Museum", this planted the seed of an idea, but the actual museum did not open until 1868.

Animals as objects are not good or bad in themselves but represent relics of a society seen by some as an oppressive symbolism, and how they are interpreted, can be challenging. There are important research and interpretation factors when working with collections, including remembering that natural history is intertwined with a colonial 
cultural context. ${ }^{15}$ But viewers should also take care not to draw assumptions too quickly and hasten items of the past to be hidden. We all carry our own preconceptions when we look at animals. It is important to keep an open mind, and sometimes some questions should be asked of what we don't see, or what hasn't been collected.

Museum collecting is also often incorrectly blamed for driving species to extinction. The Victorians had a very different relationship with death than we do today. During that period there was an explosion in taxidermy creativity and techniques, fuelled by public demand for curiosities that represented the natural world. In the context of the time, the practice of preparing taxidermy for display was a branch of an enormous industrial skin, fur, and feather trade. Taxidermy fell out of public fashion rather early, around the time of the Great War ${ }^{16}$, although other forms of the fur and skin trade continued. Museums remained as one of the only prominent places where the public could see large taxidermy collections. A lot of what we know about extinct species, like the huia, for example, comes from the remains kept and cared for by museums, not the birds shot for their tail feathers and ivorybills. Rarely seen anymore are the once popular zoomorphic objects: rhino feet ice buckets, baboons holding silver drinking trays, elephant trunk lamps, or tiger skin rugs. We have forgotten that these were high fashion commodities for interior design. Similar cultural amnesia is setting in now around the volumes of fur coats, reptile handbags, and birds perched atop hats. Fashions fade and society forgets.

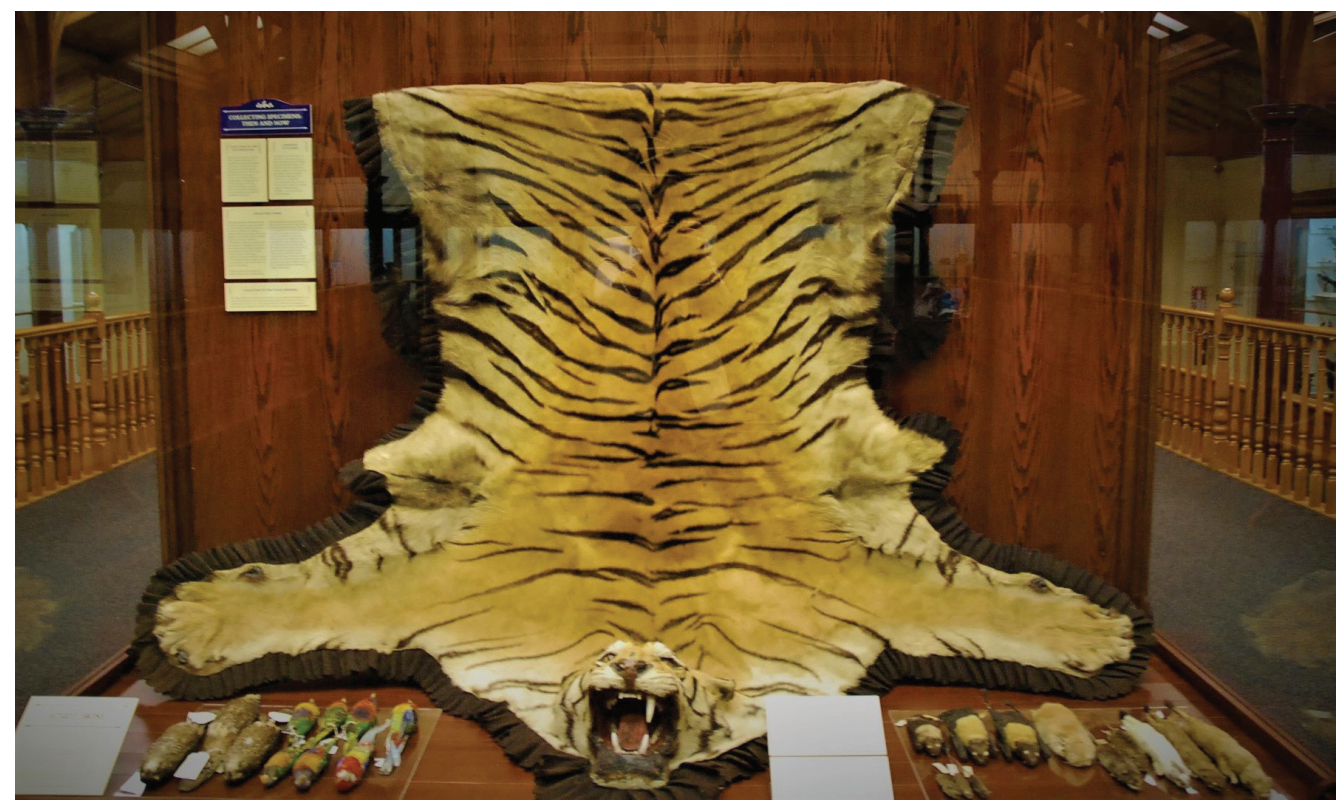

Figure 5. Preparations of different purpose. One of the few examples of zoomorphic taxidermy in the natural science collection among scientific study skins on display in the Animal Attic. Bengal Tiger skin rug, Panthera tigris VT728 (c) Otago Museum, Dunedin.

Today our collecting practices are guided by museum industry ethics ${ }^{17}$, as well as multiple layers of international legislation. In New Zealand, it is also guided by the national wildlife and marine mammals act, consultation and working with manawhenua, and adhering to local permission processes. Most of what we collect are salvaged specimens those that have died by natural causes, accident or have been euthanized by the Department of Conservation. This further reduces the impact on wild populations. It is not random, however, but guided by a collecting strategy that addresses gaps, focuses on our region, and responds to some of the most pressing environmental issues of the day.

Recent fires at the National Museum of Brazil, and New Delhi's National Museum of Natural History, have meant vast international collections have been lost. It reminds us that museums are not necessarily the hall of permanence 
and perpetuity that we promote. They require significant investment to build, maintain, and sustain. Since the 1980's museums have increasingly focussed on business viability, where ticketing, entertainment, tourism and merchandise are used to support the financial bottom line. As such, the traditional focus on taxonomy, research, and academic interpretation have diminished, due to cost pressures and notions of unprofitability. In the mid-1950s, the Otago Museum was enacted to a board of regional representatives, so our collections must also reflect the community. As an organisation, the Museum is constantly considering ways to better balance our support structures, including financial, scholarship, and community. We need people to care about collections. The "living dead" in museums are demonstrably important - not just for education and cultural reasons, but for wider environmental reasons too. They are easy for the living to ignore, and they need louder voices speaking for them. They are not just objects, artefacts, or relics of the past; they are valued organisms. If we want to protect biodiversity, and understand changes in our environment, we need to sustain natural history collections as our reference libraries of life.

Emma Burns is a Curator of Natural Science at the Otago Museum. Her role as a curator has an ambidextrous focus on what's displayed front of house and activities behind the scenes. It involves looking backwards into the past and forward into the future and across all taxa.

I "London museums urged to show more 'hidden' artefacts," BBC, 19 January 20 I I. https://www.bbc.com/news/uk-englandlondon-12214145 (accessed 14 March 2020).

2 Mike Dickison, "What's the point of museums?" New Zealand Geographic, Opinion (2018), https://www.nzgeo.com/stories/ whats-the-point-of-museums/

3 Ethics Working Group of the International Council of Museums International Committee for Museums and Collections of Natural History (ICOM NATHIST), "ICOM code of ethics for Natural History Museums," (ICOM 20 I3).

4 Taxonomy Decadal Plan Working Group, Discovering Diversity: A decadal plan for taxonomy and biosystematics in Australia and New Zealand 2018-2028 (Canberra: Australian Academy of Science and Wellington, Royal Society Te Apārangi, 20 I 8).

5 EdYong, "Natural History Museums are teeming with undiscovered species," The Atlantic (20 I 6).

6 Department of Conservation, "The New Zealand Biodiversity Strategy, Strategy Period: 2000-2020" (Wellington New Zealand: Department of Conservation, February 2000).

7 Janet M. Bradford-Grieve "Is there a taxonomic crisis?" New Zealand Science Review 73 (2016): 3-4.

8 Paola Viscardi, “Natural history collections - Why are they relevant?" The Guardian (2016).

9 John E Cooper and Gordon Hull, Gorilla Pathology and Health: With a Catalogue of Preserved Materials (San Diego: Academic Press, 2017).

10 Peter Gaze, Tuatara recovery plan 200 I-201 I. Threatened Species Recovery Plan 47 ( Government of New Zealand: Biodiversity Recovery Unit, Department of Conservation, 200 I), ISBN 978-0-478-22I 3 I-2.

II Scott Jarvie, "Reintroduction biology of tuatara (Sphenodon punctatus): identifying suitable founder animals and conservation translocation sites" (Doctor of Philosophy thesis, University of Otago, 20 I7).

12 Michael SWebster, "The Extended Specimen: Emerging Frontiers in Collections-Based Ornithological Research" in Studies in Avian Biology (CRC Press, Taylor \& Francis Group, 2017).

13 Natalie Cooper, Alexander L Bond, Joshua L Davis, Roberto Portela Miguez, Louise Tomsett, and Kristofer M Helgen, "Sex biases in bird and mammal natural history," Proceedings of the Royal Society B 286 (2019): 2019-2025, http://doi.org/ I 0. I 098/ rspb.2019.2025. 
I4 Roberte Guralnick and Jeremy Van Cleve, "Strengths and weaknesses of museum and national survey data sets for predicting regional species richness: Comparative and combined approaches," Diversity and Distributions II (2005): 349-359, https://doi. org/10.1 I I I/j.1366-9516.2005.00164.x

15 Nicole Heller, "Natural History Museums have never been more necessary" Apollo, The International Art Magazine 13 (December 20 8), https://www.apollo-magazine.com/natural-history-museums-have-never-been-more-necessary/

16 Alexis Turner, Taxidermy (New York, Rizzoli, 20I3), ISBN: 978-0-8478-4097-7.

17 Ethics Working Group of the International Council of Museums International Committee for Museums and Collections of Natural History (ICOM NATHIST), "ICOM code of ethics for Natural History Museums," (ICOM 20 I3). 